\title{
Agnieszka Polus
}

Uniwersytet Mikołaja Kopernika w Toruniu

polus.agnieszka@gmail.com

\section{Roszczenia odszkodowawcze przysługujące byłym właścicielom tzw. gruntów warszawskich}

\author{
Claims for Compensation Attributed to Former Owners \\ of the So-Called Warsaw Land
}

\section{STRESZCZENIE}

Główny przedmiot rozważań dotyczy gruntów warszawskich, które na mocy dekretu z dnia 26 października 1945 r. o własności i użytkowaniu gruntów na obszarze miasta stołecznego Warszawy przeszły z dniem 21 listopada 1945 r. na własność gminy Warszawy. Nowelizacje przepisów Kodeksu cywilnego i Kodeksu postępowania administracyjnego wprowadziły istotne zmiany w zakresie dochodzenia roszczeń odszkodowawczych. W opracowaniu przedstawiono sposób dochodzenia roszczeń zarówno według stanu prawnego sprzed 1 września 2004 r., jak i po wejściu w życie nowelizacji Kodeksu cywilnego i Kodeksu postępowania administracyjnego. Ustalenia w tym zakresie zostały wzbogacone o aktualne orzecznictwo.

Słowa kluczowe: stwierdzenie nieważności decyzji; przedawnienie; przerwanie biegu terminu przedawnienia; postępowanie administracyjne; prawo użytkowania wieczystego; roszczenie o odszkodowanie

\section{WPROWADZENIE}

Sprawa roszczeń przysługujących byłym właścicielom tzw. gruntów warszawskich, które na mocy dekretu z dnia 26 października 1945 r. o własności i użytkowaniu gruntów na obszarze miasta stołecznego Warszawy ${ }^{1}$ przeszły z dniem 21 listopada 1945 r. na własność gminy m.st. Warszawy, budzi obecnie wiele kontrowersji w praktyce obrotu prawnego. Kwestia ta była wielokrotnie przedmio-

\footnotetext{
${ }^{1}$ Dz.U. nr 50, poz. 279, dalej jako: dekret.
} 
tem rozważań Sądu Najwyższego. Ostatnio Sąd Najwyższy odniósł się do niej w uchwale z dnia 13 lipca 2016 r. $^{2}$

Celem niniejszego artykułu jest przybliżenie rozwiązań jurydycznych w zakresie roszczeń odszkodowawczych, przysługujących byłym właścicielom tzw. gruntów warszawskich, na tle zmian regulacji prawnych. W szczególności zaprezentowane zostaną wybrane roszczenia przysługujące byłym właścicielom tzw. gruntów warszawskich. Podjęte zostaną również rozważania odnoszące się do kwestii, czy możliwe byłoby de lege lata złagodzenie skutków przedawnienia roszczeń odszkodowawczych przysługujących byłym właścicielom tzw. gruntów warszawskich w oparciu o art. 5 Kodeksu cywilnego³.

\section{ROSZCZENIE ODSZKODOWAWCZE ZA WYWŁASZCZONE NIERUCHOMOŚCI NA PODSTAWIE ART. 215 USTAWY Z DNIA 21 SIERPNIA 1997 R. O GOSPODARCE NIERUCHOMOŚCIAMI}

Początkowo kwestia odszkodowania za przejęte przez Skarb Państwa grunty, budynki i inne części składowe nieruchomości była uregulowana (w zakresie podstawy materialnoprawnej) w art. 7 ust. 5 oraz w art. 8 dekretu. Z kolei sposób wypłaty odszkodowania został uregulowany w treści przepisu art. 9 wskazanego dekretu. Stanowił on, że odszkodowanie za grunty (art. 7 ust. 5 dekretu), a także budynki (art. 8 dekretu) miała ustalać specjalnie powołana do tego celu miejska komisja szacunkowa. Odszkodowanie miało wynosić - jeżeli chodzi o grunty - skapitalizowaną wartość czynszu dzierżawnego (opłaty za prawo zabudowy) gruntu tej samej wartości użytkowej, a jeżeli chodzi o budynki - wartość budynków. Warto przy tym podkreślić, że Minister Administracji Publicznej i Skarbu nigdy nie wydał rozporządzenia określającego skład i tryb postępowania miejskiej komisji, zasady i sposób ustalenia odszkodowania oraz przepisy dotyczące sposobu emisji papierów wartościowych przeznaczonych na ten cel.

Pierwsze istotne próby uporządkowania wskazanej sytuacji prawnej byłych właścicieli tzw. gruntów warszawskich wprowadziły przepisy ustawy z dnia 12 marca 1958 r. o zasadach i trybie wywłaszczania nieruchomości ${ }^{4}$. Zmiany regulacji dotyczyły m.in. zakresu przedmiotowego dochodzonych roszczeń. W nowej regulacji przyjęto, że odszkodowanie miało przysługiwać za gospodarstwa rolne, sadownicze i warzywnicze, domy jednorodzinne oraz działki budowlane, które na podstawie dekretu przeszły na własność państwa. Należałoby podnieść,

${ }^{2}$ III CZP 14/16, „Monitor Prawniczy” 2016, nr 16, s. 835.

${ }^{3}$ Ustawa z dnia 23 kwietnia 1964 r. - Kodeks cywilny (Dz.U. nr 16, poz. 93 ze. zm.), dalej jako: k.c.

${ }^{4}$ Dz.U. z 1958 r., nr 17, poz. 70, dalej jako: u.w.n. 
że odszkodowania przewidziane przez przepisy dekretu zostały urzeczywistnione w stosunku do niektórych kategorii nieruchomości ${ }^{5}$.

Omawiana ustawa, zmieniająca treść przepisu art. 53 ust. 1 i 2 u.w.n. ${ }^{6}$, wprowadziła także pewne modyfikacje, jeśli chodzi o zakres temporalny. Komentowany przepis przewidywał odszkodowanie za wywłaszczone nieruchomości, jeżeli byli właściciele gruntów lub ich następcy prawni zostali pozbawieni ich użytkowania po dniu wejścia w życie ustawy (tj. po 5 kwietnia 1958 r.). Szczegółowe kwestie dotyczące roszczeń odszkodowawczych zostały unormowane w treści przepisów art. 7-14 u.w.n.

Kolejna znacząca zmiana w sytuacji prawnej byłych właścicieli gruntów warszawskich nastąpiła na podstawie ustawy z dnia 29 kwietnia 1985 r. o gospodarce gruntami i wywłaszczaniu nieruchomości ${ }^{7}$ (weszła w życie z dniem 1 sierpnia 1985 r.). Problematyka odszkodowań za wywłaszczenie nieruchomości została uregulowana w szczególności w treści przepisu art. 83 ustawy o gospodarce gruntami i wywłaszczaniu nieruchomości. Przepis ten regulował sposób dochodzenia odszkodowań za wywłaszczone nieruchomości w sytuacji, w której właściciele lub następcy prawni zostali pozbawieni faktycznego władania gospodarstwem rolnym, domem jednorodzinnym lub działką po dniu 5 kwietnia 1958 r. Regulacja ta została powtórzona w art. 215 ustawy z dnia 21 sierpnia 1997 r. o gospodarce nieruchomościami ${ }^{8}$. Przepisy intertemporalne przewidywały, że jeżeli sprawa o odszkodowanie za nieruchomość nie została rozpoznana do dnia 1 sierpnia 1985 r., to od tej daty mogła być rozpatrywana tylko na podstawie art. 83 ustawy z dnia 29 kwietnia 1985 r. o gospodarce gruntami i wywłaszczaniu nieruchomości, zaś od dnia 1 stycznia 1998 r. - na podstawie art. 215 ustawy z dnia 21 sierpnia 1997 r. o gospodarce nieruchomościami9.

W obecnie obowiązującej regulacji ustawodawca ograniczył krąg podmiotów uprawnionych do dochodzenia roszczenia odszkodowawczego za wywłaszczone nieruchomości do poprzednich właścicieli bądź ich następców prawnych, którzy zostali pozbawieni faktycznej możliwości władania nieruchomością po dniu 5 kwietnia 1958 r. Osoby niespełniające ustawowych przesłanek nie mają możliwości ubiegania się o odszkodowanie za utracone grunty ${ }^{10}$.

W myśl regulacji przewidzianej w art. 215 u.g.n. zdarzeniem powodującym odpowiedzialność odszkodowawczą jest pozbawienie poprzedniego właściciela

${ }^{5}$ M. Górski, Problematyka własności nieruchomości warszawskich w okresie PRL i przemian ustrojowych, Toruń 2006, s. 51.

${ }^{6}$ Do ujednolicenia tekstu ustawy, tj. 6 kwietnia 1961 r., był to art. 50.

${ }^{7}$ Dz.U. z 1985 r., nr 22, poz. 99.

${ }^{8}$ Dz.U. z 1997 r., nr 115, poz. 741 ze zm., dalej jako: u.g.n.

${ }^{9}$ Wyrok WSA w Warszawie z dnia 23 września 2005 r., I SA/Wa 1692/04, Legalis nr 1131315.

${ }^{10}$ Wyrok WSA w Warszawie z dnia 21 września 2006 r., I SA/Wa 957/06, Legalis nr 354308. 
bądź jego następcy prawnego faktycznej możliwości władania nieruchomością ${ }^{11}$. Przepisy art. 215 u.g.n. dotyczące odszkodowań za wywłaszczone nieruchomości stosuje się odpowiednio do odszkodowania za gospodarstwo rolne, dom jednorodzinny oraz działkę, która przed dniem wejścia w życie dekretu mogła być przeznaczona pod budownictwo jednorodzinne, jeżeli poprzedni właściciel lub jego następcy prawni zostali pozbawieni faktycznej możliwości władania nią po dniu 5 kwietnia 1958 r. Warto wskazać, że odszkodowanie, o którym mowa w art. 215 u.g.n., dotyczy tylko niektórych nieruchomości, zaś przepisy art. 7 ust. 5 i art. 8 dekretu regulowały odszkodowanie za wywłaszczoną nieruchomość i wszystkie budynki nadające się do użytkowania lub naprawy położone na gruncie, który przeszedł na własność gminy. Powstały wątpliwości, czy przepis art. 215 ust. 2 u.g.n. w zakresie, w jakim ogranicza odszkodowania za wywłaszczone nieruchomości do domu jednorodzinnego i działki pod budowę domu jednorodzinnego, jest zgodny z Konstytucją RP.

W tym zakresie należy odnieść się do wyroku Trybunału Konstytucyjnego, który uznał, że art. 215 ust. 2 u.g.n. w zakresie, w jakim pomija stosowanie przepisów u.g.n. dotyczących odszkodowań za wywłaszczone nieruchomości do nieruchomości, które przeszły na własność gminy m.st. Warszawy lub państwa na podstawie dekretu innych niż domy jednorodzinne, jeżeli przeszły one na własność państwa po 5 kwietnia 1958 r. (działek, które przed dniem wejścia w życie powołanego dekretu mogły być przeznaczone pod budownictwo inne niż jednorodzinne), jeżeli poprzedni właściciele lub ich następcy prawni zostali pozbawieni faktycznej możliwości władania nimi po 5 kwietnia 1958 r., jest niezgodny z art. 64 ust. 2 w zw. z art. 32 ust. 1 oraz w zw. z art. 31 ust. 3 Konstytucji RP ${ }^{12}$. Niekonstytucyjność zaskarżonego przepisu w zakresie, w jakim pomija określone regulacje, nie powoduje utraty mocy obowiązującej tego przepisu, a jedynie wskazuje na potrzebę ustanowienia regulacji prawnych polegającą na wprowadzeniu do porządku prawnego przepisu, który usunąłby niekonstytucyjne pominięcie w art. 215 ust. 2 u.g.n. ${ }^{13}$ Wydanie aktu normatywnego niezgodnego z Konstytucją powoduje konieczność ustanowienia określonych przepisów, będących konsekwencją związania ustawodawcy treścią wyroku Trybunału Konstytucyjnego ${ }^{14}$. Można uznać, że niewydanie aktu normatywnego w tej sytuacji jest pominięciem legislacyjnym (ustawodawca dokonał regulacji w sposób niepełny, fragmentaryczny), o którym jest mowa w art. $417^{1} \S 4$ k.c. Konsekwencją przyjęcia takiego stanowiska jest uznanie, że po stronie byłych właścicieli tzw. gruntów war-

${ }^{11}$ A. Prusaczyk, Komentarz do art. 215, [w:] Ustawa o gospodarce nieruchomościami. Komentarz, red. J. Jaworski, A. Prusaczyk, A. Tułodziecki, M. Wolanin, Warszawa 2015, nb. 1.

${ }^{12}$ Wyrok TK z dnia 13 czerwca 2011 r., SK 41/09, Legalis nr 332311.

${ }^{13}$ A. Prusaczyk, op. cit., nb. 18.

${ }^{14}$ M. Safjan, Odpowiedzialność odszkodowawcza z tytułu bezprawia normatywnego, „Ruch Prawniczy, Ekonomiczny i Socjologiczny" 2005, nr 1, s. 25-26. 
szawskich (których składniki majątkowe nie zostały wymienione w art. 215 ust. 2 u.g.n.) powstała szkoda wyrządzona przez niewydanie aktu normatywnego. Podkreślić należy, że odpowiedzialność odszkodowawczą Skarbu Państwa z tytułu pominięcia legislacyjnego na podstawie art. $417^{1} \S 4$ k.c. można przyjąć wówczas, gdy z przepisów upoważniających wynika obowiązek legislacyjny oraz gdy przepis nakładający ten obowiązek określa pewną minimalną treść składającą się na prawo podmiotowe, w szczególności: adresatów uprawnionych do dochodzenia roszczenia i zobowiązanych do spełnienia świadczenia składającego się na treść roszczenia oraz jego zakres ${ }^{15}$.

\section{ROSZCZENIE ODSZKODOWAWCZE ZA SZKODĘ PONIESIONĄ NA SKUTEK WYDANIA DECYZJI DEKRETOWEJ Z NARUSZENIEM ART. $156 \S 1$ K.P.A.}

Roszczenie odszkodowawcze za szkodę powstałą na skutek wydania decyzji dekretowej z naruszeniem przepisu art. $156 \S 1$ k.p.a. albo stwierdzenia nieważności takiej decyzji zostało uregulowane w art. 160 k.p.a. Przepis ten został uchylony ustawą z dnia 17 czerwca 2004 r. o zmianie ustawy - Kodeks cywilny oraz niektórych innych ustaw ${ }^{16}$. Pojawia się kwestia, czy może on w aktualnym obrocie prawnym mieć zastosowanie w procesie dochodzenia roszczeń odszkodowawczych przez właścicieli gruntów warszawskich.

Zgodnie z treścią przepisu art. 5 wskazanej ustawy zmieniającej do stanów prawnych powstałych przed 1 września 2004 r. stosuje się art. 160 k.p.a. i przepisy k.c. w brzmieniu obowiązującym do tego dnia. Enigmatyczna regulacja tego przepisu spowodowała liczne rozbieżności w zakresie intertemporalnym. Do wskazanej kwestii odniósł się Sąd Najwyższy, uznając, że do roszczeń o naprawienie szkody spowodowanej wadliwą decyzją administracyjną wydaną przed 1 września 2004 r., której nieważność została stwierdzona po tym dniu, ma zastosowanie art. 160 § 1-3 i 6 k.p.a. ${ }^{17}$ Należy jednocześnie zaznaczyć, że Sąd Najwyższy wykluczył możliwość dalszego stosowania art. 160 § 4 i 5 k.p.a. Przepis art. 5 omawianej ustawy zmieniającej nie rozstrzyga o czasowym zakresie stosowania art. $160 \S 4$ i 5 k.p.a. Zastosowanie znajduje tutaj jedna z podstawowych zasad prawa międzyczasowego (intertemporalnego) - zasada bezpośredniego stosowania nowego prawa. Przekładając ją na kanwę analizowanej problematyki, należałoby skonstatować, że od dnia wejścia w życie ustawy zmieniającej właściwym

\footnotetext{
${ }^{15}$ Wyrok SA w Warszawie z dnia 8 listopada 2013 r., I ACa 894/13, Legalis nr 1048883.

${ }^{16}$ Dz.U. nr 162, poz. 1692. Ustawa weszła w życie 1 września 2004 r. Dalej jako: ustawa zmieniająca.

${ }^{17}$ Uchwała SN z dnia 31 marca 2011 r., III CZP 112/10, Legalis nr 299305.
} 
trybem dochodzenia roszczeń odszkodowawczych za szkodę spowodowaną wadliwą decyzją administracyjną jest postępowanie sądowe ${ }^{18}$.

Większość postępowań odszkodowawczych dotyczących tzw. gruntów warszawskich odnosi się do zdarzeń, które powstały przed 1 września 2004 r. Stąd zasadne wydaje się przedstawienie trybu dochodzenia roszczeń na podstawie art. 160 k.p.a. Początkowo postępowanie na podstawie art. 160 k.p.a. było dwuetapowe. Pierwszy etap dochodzenia roszczenia za szkodę spowodowaną wydaniem decyzji to postępowanie przed organem administracji publicznej, który stwierdził nieważność decyzji dekretowej. Postępowanie to kończyło się wydaniem decyzji o przyznaniu lub odmowie przyznania odszkodowania. Jeżeli strona była zadowolona z przyznanego jej odszkodowania, postępowanie administracyjne ulegało zakończeniu. Wydana decyzja stawała się tym samym ostateczna i stanowiła tytuł egzekucyjny podlegający wykonaniu w drodze egzekucji sądowej ${ }^{19}$.

Decyzja odmawiająca przyznania odszkodowania była podstawą wszczęcia drugiego etapu postępowania (postępowanie sądowe). Strona poszkodowana nie mogła wystąpić na drogę sądową przed wydaniem rozstrzygnięcia przez organ administracji właściwy do orzekania w sprawie ${ }^{20}$. Występowała czasowa niedopuszczalność drogi sądowej. W orzecznictwie podkreślano, że skoro roszczenie realizowane było dwustopniowo (najpierw na drodze administracyjnej, a następnie na drodze sądowej) i jednocześnie konieczne było wyczerpanie drogi administracyjnej, to zachodziła wówczas niedopuszczalność drogi sądowej (do momentu wydania decyzji w przedmiocie przyznania lub odmowie przyznania odszkodowania) ${ }^{21}$. W związku z możliwością wniesienia przez stronę powództwa odszkodowawczego do sądu powszechnego decyzja administracyjna w przedmiocie odszkodowania nie miała cech formalnej prawomocności ${ }^{22}$.

Warto nadmienić, że wytoczenie powództwa cywilnego nie stanowiło wszczęcia postępowania odwoławczego, ponieważ sądy powszechne nie są władne dokonywać oceny prawidłowości wydanych decyzji administracyjnych i orzekać w przedmiocie istnienia lub nieistnienia materialnoprawnych przesłanek stanowiących podstawę wydania decyzji $\mathrm{i}^{23}$.

\section{${ }^{18}$ Ibidem.}

${ }^{19}$ H. Ciepiela, R. Sarbiński, K. Sobczyk-Sarbińska, Roszczenia przystugujące byłym właścicielom tzw. gruntów warszawskich - sposób ich dochodzenia w postępowaniu administracyjnym $i$ sqdowym, Warszawa 2013, s. 944. Zob. uchwała SN z dnia 7 lutego 1997 r., III CZP 1/97, OSN 1997, nr 8, poz. 98.

${ }^{20}$ M. Górski, op. cit., s. 134.

${ }^{21}$ Postanowienie SN z dnia 30 sierpnia 1988 r., IV CZ 111/88, Legalis nr 26396.

${ }^{22}$ H. Ciepiela, R. Sarbiński, K. Sobczyk-Sarbińska, op. cit., s. 268.

${ }^{23}$ Wyrok TK z dnia 5 września 2005 r., P 18/04, Legalis nr 70000. Zob. J. Kremis, Odpowiedzialność Skarbu Państwa za decyzje administracyjne wedlug kodeksu cywilnego i kodeksu postępowania administracyjnego, Wrocław 1986, s. 158-161. 
Powództwo o odszkodowanie dawało początek nowej sprawie, zaś sąd nie był związany ustaleniami oraz oceną prawną organu administracji publicznej ${ }^{24}$. Zgodnie z regulacją art. $160 \S 5$ k.p.a. na wniesienie powództwa do sądu powszechnego przysługiwał 30 -dniowy termin, liczony od dnia doręczenia decyzji. Termin ten zaliczany był do terminów procesowych. W razie uchybienia temu terminowi możliwe było jego przywrócenie ${ }^{25}$. Wniesienie powództwa odszkodowawczego zostało obwarowane przez ustawodawcę bardzo krótkim terminem. Często nie był on dochowywany przez byłych właścicieli tzw. gruntów warszawskich. Kwestia ta budziła liczne kontrowersje. Ostatecznie 30-dniowy termin na wniesienie powództwa do sądu powszechnego został uznany przez Trybunał Konstytucyjny za rażąco krótki w porównaniu $\mathrm{z}$ terminem przedawnienia roszczeń określonych w Kodeksie cywilnym ${ }^{26}$. Na mocy orzeczenia wydanego przez Trybunał Konstytucyjny art. $160 \S 5$ k.p.a. został uznany za niezgodny z art. 32 ust. 1 i art. 64 ust. 2 Konstytucji RP.

W sprawach wydania ostatecznej decyzji nadzorczej po 1 września $2004 \mathrm{r}$. administracyjny etap dochodzenia odszkodowania nie ma już zastosowania. Byli właściciele nieruchomości przejętych na mocy dekretu z 1945 r. lub ich następcy prawni mogą bezpośrednio wystąpić z powództwem do sądu powszechnego ${ }^{27}$. Sytuacja strony jest bardziej skomplikowana w sprawach, w których zarówno decyzja dekretowa, jak i decyzja stwierdzająca nieważność tej decyzji zostały wydane przed 1 września 2004 r. Wówczas prima facie wydaje się, że konieczne jest przeprowadzenie postępowania administracyjnego i uzyskanie prejudykatu w postaci decyzji odmawiającej przyznania odszkodowania na podstawie art. 160 $\S 4$ k.p.a., a następnie wystąpienie z powództwem cywilnym o odszkodowanie. Podobne stanowisko zajął Sąd Najwyższy w sprawie, w której decyzja nadzorcza została wydana w dniu 30 września 2003 r., sąd uznał, że zachodzi czasowa niedopuszczalność drogi sądowej wynikająca z brzmienia art. 160 § 4 k.p.a. Zgodnie z tym przepisem wystąpienie na drogę sądową powinno być poprzedzone złożeniem wniosku o przyznanie odszkodowania i dopiero decyzja odmowna w postępowaniu administracyjnym otwiera drogę sądową dla dochodzenia odszkodowania $^{28}$.

Powstaje kwestia, czy postępowanie administracyjne, toczące się w przedmiocie odszkodowania z art. $160 \S 4$ k.p.a., zawiesza bieg terminu przedawnienia roszczenia, o którym mowa w art. $160 \S 6$ k.p.a. Skoro strona nie może wystąpić z powództwem do sądu powszechnego do czasu wydania rozstrzygnięcia w przedmiocie odszkodowania, słuszne wydaje się zawieszenie biegu

\footnotetext{
${ }^{24}$ H. Ciepiela, R. Sarbiński, K. Sobczyk-Sarbińska, op. cit., s. 269.

${ }^{25}$ M. Górski, op. cit., s. 136 i literatura tam powołana.

${ }^{26}$ Wyrok TK z dnia 5 września 2005 r., P 18/04, Legalis nr 70000.

${ }^{27}$ H. Ciepiela, R. Sarbiński, K. Sobczyk-Sarbińska, op. cit., s. 270.

${ }^{28}$ Wyrok SN z dnia 9 marca 2012 r., I CSK 277/11, Legalis nr 490930.
} 
terminu przedawnienia roszczenia na okres postępowania przed organem administracji. Stanowisko takie prezentuje także doktryna, uznając, że jeżeli decyzja nadzorcza została wydana przed 1 września 2004 r. i poszkodowani wystąpili o odszkodowanie w trybie art. $160 \S 4$ k.p.a., a decyzja w tym przedmiocie nie została wydana przed tą datą, to brak jest podstaw do zwrotu wniosku ${ }^{29}$. Organ administracji publicznej wydaje decyzję w sprawie, a strona niezadowolona z jej treści może wnieść powództwo do sądu powszechnego. W tej sytuacji wniesienie żądania przerywa bieg terminu przedawnienia. W przypadku, gdy żądanie nie zostało skierowanie do dnia 1 września 2004 r., strona może bezpośrednio wystąpić z powództwem do sądu powszechnego ${ }^{30}$.

Stronie, która poniosła szkodę na skutek wydania decyzji z naruszeniem przepisu art. $156 \S 1$ k.p.a. albo na skutek stwierdzenia nieważności tej decyzji, służy roszczenie o odszkodowanie za rzeczywistą poniesioną szkodę (art. $160 \S 1$ k.p.a.). Przepis art. 160 k.p.a. jest samodzielną podstawą odpowiedzialności odszkodowawczej Skarbu Państwa. W pozostałym zakresie (nieuregulowanym w treści art. 160 k.p.a.) zastosowanie znajdują przepisy ogólne Kodeksu cywilnego $^{31}$. W szczególności wskazany art. 160 k.p.a. nie zawiera definicji legalnej pojęcia szkody. W związku z tym niezbędne jest zastosowanie w tym zakresie regulacji zawartej w Kodeksie cywilnym. Analizowana kwestia była przedmiotem refleksji Sądu Najwyższego. Według dominującego w orzecznictwie poglądu szkoda rzeczywista, o której mowa w treści przepisu art. $160 \S 1$ k.p.a., odpowiada pojęciu straty w rozumieniu treści przepisu art. $361 \S 2$ k.c. ${ }^{32}$

Warto dodać, że naprawienie szkody w myśl regulacji art. $361 \S 2$ k.c. co do zasady obejmuje straty, które poszkodowany poniósł (damnum emergens) oraz korzyści, które mógł osiągnąć (lucrum cesans). Jednakże w analizowanej kwestii odszkodowań za tzw. grunty warszawskie zakres odpowiedzialności został przez ustawodawcę ograniczony. Pominięta została możliwość dochodzenia utraconych korzyści (lucrum cesans). Regulacja zawarta w art. 160 § 1 k.p.a. ogranicza bowiem odszkodowanie za szkodę powstałą na skutek wydania decyzji z naruszeniem art. $156 \S 1$ k.p.a. albo stwierdzenia nieważności takiej decyzji tylko do szkody rzeczywistej.

Należy nadmienić, że przepis art. 160 k.p.a. w zakresie, w jakim ogranicza odszkodowanie tylko do szkody rzeczywistej, został uznany za niezgodny z art. 77 ust. 1 Konstytucji RP ${ }^{33}$. Jednocześnie Trybunał Konstytucyjny zastrzegł, że roz-

${ }^{29}$ H. Ciepiela, R. Sarbiński, K. Sobczyk-Sarbińska, op. cit., s. 273.

${ }^{30}$ Ibidem.

${ }^{31}$ J. Kremis, Odpowiedzialność Skarbu Państwa za decyzje administracyjne wedlug kodeksu cywilnego i kodeksu postępowania administracyjnego, Wrocław 1986, s. 116. Zob. uchwała SN z dnia 26 stycznia 1989 r., III CZP 58/88, OSN 1989, nr 9, poz. 129.

${ }^{32}$ Wyrok SN z dnia 21 marca 2003 r., III CZP 6/03, Legalis nr 56173.

${ }^{33}$ Wyrok TK z dnia 23 września 2003 r., K 20/02, Legalis nr 58777. 
strzygnięcie to ma zastosowanie do szkód powstałych po dniu wejścia $\mathrm{w}$ życie Konstytucji RP (17 października 1997 r.). W odniesieniu do roszczeń odszkodowawczych byłych właścicieli gruntów warszawskich bezprawne pozbawienie prawa użytkowania wieczystego może skutkować utratą korzyści w postaci czynszu za najem. W kontekście wyroku Trybunału Konstytucyjnego oznacza to, że byli właściciele tzw. gruntów warszawskich mogą dochodzić odszkodowania także za utracone korzyści (lucrum cesans) w zakresie szkód powstałych po 17 października 1997 r. W praktyce oznacza to, że uzyskanie odszkodowania za utracone korzyści, spowodowane bezprawną decyzją dekretową, jest znikome ${ }^{34}$, zwłaszcza że szkoda w postaci lucrum cesans nie powstaje równocześnie ze zdarzeniem powodującym szkodę, lecz w okresie późniejszym ${ }^{35}$.

Stopień prawnego skomplikowania spraw dekretowych, złożoność i długotrwałość postępowań administracyjnych i sądowych mogą doprowadzić do uchybienia terminu przedawnienia, o którym mowa w regulacji art. $160 \S 6$ k.p.a. $\mathrm{Z}$ przepisu tego wynika, że roszczenie o odszkodowanie przedawnia się z upływem 3 lat od dnia, w którym stała się ostateczna decyzja stwierdzająca nieważność decyzji wydanej z naruszeniem przepisu art. $156 \S 1$ k.p.a. albo decyzja, w której organ stwierdził w myśl art. 158 § 2 k.p.a., że zaskarżona decyzja została wydana z naruszeniem przepisu art. $156 \S 1$ k.p.a. Regulacja zawarta w art. 160 $\S 6$ k.p.a. stanowi lex specialis w stosunku do regulacji zawartej w Kodeksie cywilnym $^{36}$. Trzeba dodać, że ustawodawca wyznaczył odmienny sposób liczenia terminu przedawnienia, uzależniając początek tego terminu od daty wydania ostatecznej decyzji stwierdzającej nieważność decyzji dekretowej lub stwierdzenia wydania jej z naruszeniem prawa.

$\mathrm{Na}$ gruncie przepisu art. $160 \S 6$ k.p.a. powstał problem, czy decyzja nadzorcza wydana przez ministra lub Samorządowe Kolegium Odwoławcze jest ostateczna z chwilą jej doręczenia czy też przymiot ostateczności uzależniony jest od złożenia wniosku o ponowne rozpatrzenie sprawy, jak ma to miejsce de lege lata. Ustalenie tej kwestii pozwoli na wskazanie, od kiedy należy liczyć początek biegu terminu przedawnienia roszczenia odszkodowawczego (art. 160 $\S 6$ k.p.a.) po stwierdzeniu nieważności decyzji dekretowej przez Samorządowe Kolegium Odwoławcze (od chwili wydania decyzji nadzorczej przez Samorządowe Kolegium Odwoławcze czy od chwili bezskutecznego upływu terminu do złożenia wniosku o ponowne rozpoznanie sprawy). Wskazać należy, że na przestrzeni lat $\mathrm{w}$ judykaturze zarysowały się dwa rozbieżne stanowiska. Według jednego decyzja nadzorcza wydana przez ministra lub Samorządowe Kolegium Odwoławcze jest decyzją ostateczną w rozumieniu art. $160 § 6$ k.p.a., nawet jeżeli strona złożyła wniosek o ponowne rozpatrzenie sprawy zgodnie

\footnotetext{
${ }^{34}$ H. Ciepiela, R. Sarbiński, K. Sobczyk-Sarbińska, op. cit., s. 185.

${ }^{35}$ Wyrok SN z dnia 15 listopada 2010 r., IV CSK 78/10, Legalis nr 397169.

${ }^{36}$ H. Ciepiela, R. Sarbiński, K. Sobczyk-Sarbińska, op. cit., s. 252.
} 
z art. $127 \S 3$ k.p.a. ${ }^{37}$ Według drugiego za początek biegu terminu przedawnienia $\mathrm{z}$ art. $160 \S 6$ k.p.a. można uznać dopiero datę wydania decyzji w wyniku ponownego rozpatrzenia sprawy, nie zaś datę pierwszej decyzji nadzorczej ${ }^{38}$. Ostatecznie Sąd Najwyższy uznał, że jeżeli w wyniku wydania przed dniem 1 września 2004 r. decyzji z naruszeniem art. $156 \S 1$ k.p.a. albo stwierdzenia nieważności takiej decyzji strona poniosła szkodę, a właściwy minister lub Samorządowe Kolegium Odwoławcze stwierdziło po tym dniu, lecz przed 11 kwietnia 2011 r., nieważność tej decyzji albo jej wydanie z naruszeniem prawa, termin przedawnienia roszczenia o odszkodowanie przewidziany w art. $160 \S 6$ k.p.a. rozpoczyna bieg z chwilą bezskutecznego upływu terminu do złożenia wniosku o ponowne rozpatrzenie sprawy ${ }^{39}$. W przypadku złożenia wniosku o ponowne rozpoznanie sprawy bieg terminu przedawnienia rozpoczyna się z chwilą wydania decyzji po ponownym rozpatrzeniu sprawy ${ }^{40}$. Oznacza to, że jeżeli Samorządowe Kolegium Odwoławcze stwierdziło przed 11 kwietnia 2011 r. nieważność decyzji dekretowej wydanej przed 1 września 2004 r., to początek biegu terminu przedawnienia roszczenia odszkodowawczego z art. $160 \S 6$ k.p.a. rozpoczyna się $\mathrm{z}$ chwilą bezskutecznego upływu terminu do złożenia wniosku o ponowne rozpoznanie sprawy.

Jak już wcześniej wspomniano, w sprawach, w których decyzja dekretowa została wydana przed 1 września 2004 r., zaś decyzja stwierdzająca nieważność nastąpiła po tym dniu, strona może wnieść powództwo do sądu powszechnego z pominięciem administracyjnego trybu dochodzenia odszkodowania. Tym samym należy przyjąć, że skoro strona po 1 września 2004 r. nie musi wyczerpać administracyjnego trybu dochodzenia odszkodowania, to nie ma podstaw do zawieszenia biegu terminu przedawnienia roszczenia na czas trwania postępowania przed organem administracji publicznej.

Pojawia się kwestia rozpoznania wniosków byłych właścicieli tzw. gruntów warszawskich, którzy wystąpili o odszkodowanie do organu administracji publicznej, nie zaś (jak wskazuje regulacja prawna obowiązująca od 1 września 2004 r.) z powództwem do sądu powszechnego. Prima facie wystąpienie z wnioskiem o odszkodowanie do organu administracji publicznej, pomimo braku takiej konieczności, może doprowadzić do upływu terminu przedawnienia, o którym mowa w art. 160 § 6 k.p.a., zwłaszcza że postępowanie przed organem administracyjnym może zostać uznane jako wystąpienie z wnioskiem do organu nie-

${ }^{37}$ Wyrok SN z dnia 21 listopada 2008 r., V CSK 204/08, Legalis nr 138663; wyrok SN z dnia 6 listopada 2013 r., IV CSK 133/13, Legalis nr 830519.

${ }^{38}$ Wyrok SN z dnia 19 września 2013 r., I CSK 732/12, Legalis nr 924877; wyrok SN z dnia 18 grudnia 2013 r., I CSK 142/13, Legalis nr 830519.

${ }^{39}$ Uchwała SN z dnia 20 stycznia 2015 r., III CZP 78/14, Legalis nr 1163710.

${ }^{40}$ Ibidem. 
uprawnionego do rozpoznania sprawy o odszkodowanie, a tym samym nie może wywołać skutku w postaci przerwania biegu terminu przedawnienia, o którym mowa w art. $123 \S 1$ k.c. ${ }^{41}$

Tożsame stanowisko zajął Sąd Najwyższy, stwierdzając, że złożenie wniosku o przyznanie odszkodowania przerywa bieg terminu przedawnienia, o którym mowa w art. $123 \S 1$ pkt 1 k.c., jeżeli zostało złożone do organu właściwego do rozpoznania objętego nim roszczenia. Innymi słowy, złożenie wniosku do organu administracyjnego, który nie jest właściwy do jego rozpoznania, zamiast według właściwej kompetencji do sądu, nie przerywa biegu przedawnienia ${ }^{42}$.

Termin określony w art. $160 \S 6$ k.p.a. zalicza się do terminów prawa materialnego, którego niedochowanie powoduje ostateczną utratę roszczenia ${ }^{43}$. Jak wiadomo, terminy przedawnienia roszczeń są określone w przepisach ius cogens i nie mogą być skracane ani przedłużane przez czynność prawną ${ }^{44}$. Pojawia się kwestia przedawnienia roszczeń odszkodowawczych w sprawach, gdzie postępowanie administracyjne prowadzone na podstawie art. $160 \S 4$ k.p.a. zakończyło się po upływie terminu przedawnienia. Jak wcześniej wspomniano, strona nie mogła wystąpić wówczas z powództwem o odszkodowanie przed wydaniem rozstrzygnięcia przez organ administracji właściwy do orzekania w sprawie. W tych przypadkach złagodzenia skutków przedawnienia roszczeń odszkodowawczych można doszukiwać się w zastosowaniu art. 5 k.c. Ze względu na szeroki zakres stosowania art. 5 k.c., w doktrynie przyjmuje się, że można stosować go co do zasady do przepisów księgi ogólnej Kodeksu cywilnego ${ }^{45}$ (w tym przedawnienia). Stosowanie art. 5 k.c. do przedawnienia dopuszcza też Sąd Najwyższy, nie wykluczając uznania zarzutu przedawnienia za nadużycie prawa także wtedy, gdy przyczyny opóźnienia w dochodzeniu roszczenia leżą również, a nawet wyłącznie, po stronie uprawnionego ${ }^{46}$. Za zastosowaniem regulacji art. 5 k.c. do przedawnień w sprawach gruntów warszawskich przemawia rażąco krótki termin przedawnienia, dający jednostronny przywilej Skarbowi Państwa ${ }^{47}$. Warto tu zwrócić uwagę na orzeczenie Sądu Najwyższego odnoszące się do spraw, w których:

[...] postępowanie administracyjne zostało zakończone po upływie terminu przedawnienia, $\mathrm{w}$ razie podniesienia zarzutu przedawnienia roszczenia przez zobowiązanego, możliwe jest in casu zastosowanie art. 5 k.c. [...] Zastosowanie tych przepisów, w razie spełnienia przesłanek w nich

${ }^{41}$ H. Ciepiela, R. Sarbiński, K. Sobczyk-Sarbińska, op. cit., s. 271.

${ }^{42}$ Wyrok SN z dnia 12 marca 2015 r., I CSK 62/14, Legalis nr 1213078.

${ }^{43} \mathrm{~T}$. Brzezicki, Roszczenia odszkodowawcze z tytułu wzruszania decyzji administracyjnej, Toruń 2002, s. 95.

${ }^{44}$ Wyrok SA w Warszawie z dnia 28 kwietnia 2016 r., I ACa 953/15, Legalis nr 1473237.

${ }^{45}$ T. Justyński, Nadużycie prawa w polskim prawie cywilnym, Kraków 2000, s. 53.

${ }^{46}$ Wyrok SN z dnia 1 marca 2016 r., I PK 85/15, Legalis nr 1442658.

${ }^{47}$ H. Ciepiela, R. Sarbiński, K. Sobczyk-Sarbińska, op. cit., s. 267-268. 
Agnieszka Polus

określonych, uwzględnia konstytucyjną zasadę prawa do słusznego odszkodowania i powszechnego prawa do wynagrodzenia szkody wyrządzonej przez niezgodne z prawem działanie władzy publicznej (art. 21 i 77 ust. 1 Konstytucji RP) ${ }^{48}$.

Możliwość zastosowania art. 5 k.c. do przedawnień w sytuacjach, w których postępowanie administracyjne zakończyło się po upływie 3-letniego terminu przedawnienia roszczenia odszkodowawczego z art. 160 § 6 k.p.a., na którą wskazuje Sąd Najwyższy, wydaje się kompromisowym rozwiązaniem z perspektywy zasady słusznego odszkodowania za wywłaszczenie wyrażonej w art. 21 Konstytucji RP. Trzeba dodać, że przez słuszne odszkodowanie należy rozumieć odszkodowanie ekwiwalentne w stosunku do wartości wywłaszczonego dobra ${ }^{49}$. Oznacza to, że odszkodowanie to powinno umożliwić właścicielowi odtworzenie rzeczy, którą utracił ${ }^{50}$ na skutek wywłaszczenia.

Stosując art. 5 k.c., trzeba mieć jednak na względzie szczególny charakter tego przepisu, związany z zastosowaniem w nim klauzul generalnych. Dla oceny, czy podniesiony zarzut przedawnienia nie nosi znamion nadużycia prawa, należy uwzględnić charakter dochodzonego roszczenia oraz przyczyny opóźnienia ${ }^{51}$. W sprawach gruntów warszawskich, jak się wydaje, przyczyną opóźnienia w wystąpieniu $\mathrm{z}$ wnioskiem o odszkodowanie może być fakt, że w okresie biegu przedawnienia dochodzonego roszczenia toczyło się postępowanie administracyjne o rozpoznanie wniosku dekretowego, które zakończyło się dopiero po upływie terminu przedawnienia roszczenia odszkodowawczego ${ }^{52}$.

Nie bez znaczenia dla uchybienia terminu przedawnienia roszczenia odszkodowawczego są liczne zmiany regulacji prawnych oraz fakt, że przez długi okres kształtowało się orzecznictwo sądów w zakresie wpływu toczącego się postępowania administracyjnego o ustanowienie prawa użytkowania wieczystego po stwierdzeniu nieważności decyzji dekretowej na bieg terminu przedawnienia, o którym mowa w art. 160 § 6 k.p.a. ${ }^{53}$ Prima facie wydaje się, że okoliczności te mogły mieć wpływ na wystąpienie z powództwem odszkodowawczym, o którym mowa $\mathrm{w}$ art. $160 \S 1$ k.p.a. dopiero po zakończeniu postępowania administracyjnego o ustalenie prawa wieczystego użytkowania.

\footnotetext{
${ }^{48}$ Uchwała SN z dnia 13 lipca 2016 r., III CZP 14/16, „Monitor Prawniczy” 2016, nr 16, s. 835.

${ }^{49}$ Uchwała TK z dnia 29 marca 1993 r., W 13/92, Legalis nr 10156.

${ }^{50}$ Ibidem.

${ }^{51}$ Wyrok SN z dnia 2 kwietnia 2003 r., I CKN 204/01, Legalis nr 76866.

${ }^{52} \mathrm{Na}$ tę okoliczność wskazuje Sąd Najwyższy w wyroku z dnia 8 grudnia 2016 r., I CSK 1080/14, Legalis nr 1555647.

${ }^{53}$ Zob. ibidem.
} 


\section{PODSUMOWANIE}

Po stwierdzeniu nieważności decyzji dekretowej lub stwierdzeniu wydania decyzji dekretowej z naruszeniem prawa (art. $158 \S 2$ k.p.a.) były właściciel gruntu lub jego następcy prawni mogą wystąpić z roszczeniem odszkodowawczym na podstawie art. 215 u.g.n. Przesłanką odpowiedzialności z art. 215 u.g.n. jest pozbawienie poprzedniego właściciela lub jego następcy prawnego faktycznej możliwości władania nieruchomością. Przepisy art. 215 u.g.n. dotyczące odszkodowań za wywłaszczone nieruchomości stosuje się odpowiednio do odszkodowania za gospodarstwo rolne, dom jednorodzinny oraz działkę, która przed dniem wejścia w życie dekretu mogła być przeznaczona pod budownictwo jednorodzinne, jeżeli poprzedni właściciel bądź jego następcy prawni zostali pozbawieni faktycznej możliwości władania nią po dniu 5 kwietnia 1958 r. Przepis art. 215 u.g.n. dotyczy tylko niektórych nieruchomości, zaś przepisy art. 7 ust. 5 i art. 8 dekretu regulowały odszkodowanie za wywłaszczoną nieruchomość i wszystkie budynki nadające się do użytkowania lub naprawy położone na gruncie, które przeszły na własność gminy. W wyroku z dnia 13 czerwca 2011 r. Trybunał Konstytucyjny uznał, że art. $215 \S 2$ u.g.n. jest niezgodny z art. 64 ust. 2 w zw. $\mathrm{z}$ art. 32 ust. 1 oraz w zw. z art. 31 ust. 3 Konstytucji RP w zakresie, w jakim ogranicza odszkodowanie za tzw. grunty warszawskie tylko do domu jednorodzinnego i działki pod budowę domu jednorodzinnego.

Były właściciel gruntu lub jego następcy prawni mogą także wystąpić z roszczeniem o odszkodowanie na podstawie art. 160 k.p.a. (za szkodę powstałą na skutek wydania decyzji dekretowej z naruszeniem prawa lub stwierdzenia nieważności takiej decyzji). Do roszczeń o naprawienie szkody wyrządzonej ostateczną decyzją administracyjną wydaną przed 1 września 2004 r., której nieważność lub wydanie z naruszeniem art. $156 \S 1$ k.p.a. stwierdzono po tym dniu, ma zastosowanie art. $160 \S 1-3$ i 6 k.p.a. Początkowo postępowanie uregulowane w art. 160 k.p.a. było dwuetapowe i obejmowało etap administracyjny oraz sądowy. Po nowelizacji Kodeksu cywilnego i Kodeksu postępowania administracyjnego, dokonanej w 2004 r., w sprawach wydania ostatecznej decyzji stwierdzającej nieważność po 1 września 2004 r. administracyjny etap dochodzenia odszkodowania nie ma już zastosowania. Byli właściciele nieruchomości przejętych na mocy dekretu lub ich następcy prawni mogą bezpośrednio wystąpić z powództwem odszkodowawczym do sądu powszechnego. W sytuacji, gdy decyzja dekretowa została wydana przed 1 września 2004 r., a orzeczenie Samorządowego Kolegium Odwoławczego stwierdzające jej nieważność wydano po 1 września 2004 r., nie można uznać organu administracji publicznej za organ powołany do rozpoznawania sprawy. Innymi słowy, jeżeli strona wystąpi z wnioskiem o odszkodowanie (art. $160 \S 4$ k.p.a.) na podstawie decyzji stwierdzającej nieważność decyzji wydanej po 1 września 2004 r., nie można zawiesić biegu termi- 
nu przedawnienia na okres postępowania przed organem administracji publicznej. 3-letni termin przedawnienia rozpoczyna bieg od czasu, w którym stała się prawomocna decyzja stwierdzająca nieważność decyzji dekretowej. Jeżeli strona wystąpi z powództwem do sądu po upływie terminu przedawnienia, roszczenie staje się bezskuteczne, ponieważ termin przedawnienia, o którym mowa w art. 160 $\S 6$ k.p.a., jest terminem prawa materialnego, a więc nie można go przywrócić.

Złagodzenia skutków przedawnienia roszczeń w sprawach, gdzie postępowanie administracyjne prowadzone na podstawie art. $160 \S 4$ k.p.a. zakończyło się po upływie terminu przedawnienia, można doszukiwać się w zastosowaniu art. 5 k.c. Zastosowanie art. 5 k.c. do przedawnienia dopuszcza także Sąd Najwyższy.

\section{BIBLIOGRAFIA}

Brzezicki T., Roszczenia odszkodowawcze z tytułu wzruszania decyzji administracyjnej, Torun 2002. Ciepiela H., Sarbiński R., Sobczyk-Sarbińska K., Roszczenia przystugujące byłym właścicielom tzw. gruntów warszawskich - sposób ich dochodzenia w postępowaniu administracyjnym i sądowym, Warszawa 2013.

Dekret z dnia 26 października 1945 r. o własności i użytkowaniu gruntów na obszarze miasta stołecznego Warszawy (Dz.U. nr 50, poz. 279).

Górski M., Problematyka własności nieruchomości warszawskich w okresie PRL i przemian ustrojowych, Torun 2006.

Justyński T., Nadużycie prawa w polskim prawie cywilnym, Kraków 2000.

Kremis J., Odpowiedzialność Skarbu Państwa za decyzje administracyjne wedlug kodeksu cywilnego i kodeksu postępowania administracyjnego, Wrocław 1986.

Postanowienie SN z dnia 30 sierpnia 1988 r., IV CZ 111/88, Legalis nr 26396.

Prusaczyk A., Komentarz do art. 215, [w:] Ustawa o gospodarce nieruchomościami. Komentarz, red. J. Jaworski, A. Prusaczyk, A. Tułodziecki, M. Wolanin, Warszawa 2015.

Safjan M., Odpowiedzialność odszkodowawcza z tytułu bezprawia normatywnego, „Ruch Prawniczy, Ekonomiczny i Socjologiczny" 2005, nr 1.

Uchwała SN z dnia 26 stycznia 1989 r., III CZP 58/88, OSN 1989, nr 9, poz. 129.

Uchwała SN z dnia 7 lutego 1997 r., III CZP 1/97, OSN 1997, nr 8, poz. 98.

Uchwała SN z dnia 31 marca 2011 r., III CZP 112/10, Legalis nr 299305.

Uchwała SN z dnia 20 stycznia 2015 r., III CZP 78/14, Legalis nr 1163710.

Uchwała SN z dnia 13 lipca 2016 r., III CZP 14/16, „Monitor Prawniczy” 2016, nr 16.

Uchwała TK z dnia 29 marca 1993 r., W 13/92, Legalis nr 10156.

Ustawa z dnia 12 marca 1958 r. o zasadach i trybie wywłaszczania nieruchomości (Dz.U. z 1958 r., nr 17, poz. 70).

Ustawa z dnia 23 kwietnia 1964 r. - Kodeks cywilny (Dz.U. nr 16, poz. 93 ze. zm.).

Ustawa z dnia 29 kwietnia 1985 r. o gospodarce gruntami i wywłaszczaniu nieruchomości (Dz.U. z 1985 r., nr 22, poz. 99).

Ustawa z dnia 21 sierpnia 1997 r. o gospodarce nieruchomościami (Dz.U. z 1997 r., nr 115, poz. $741 \mathrm{ze} \mathrm{zm}$.).

Ustawa z dnia 17 czerwca 2004 r. o zmianie ustawy - Kodeks cywilny oraz niektórych innych ustaw (Dz.U. nr 162, poz. 1692).

Wyrok SA w Warszawie z dnia 8 listopada 2013 r., I ACa 894/13, Legalis nr 1048883.

Wyrok SA w Warszawie z dnia 28 kwietnia 2016 r., I ACa 953/15, Legalis nr 1473237. 
Wyrok SN z dnia 21 marca 2003 r., III CZP 6/03, Legalis nr 56173.

Wyrok SN z dnia 2 kwietnia 2003 r., I CKN 204/01, Legalis nr 76866.

Wyrok SN z dnia 21 listopada 2008 r., V CSK 204/08, Legalis nr 138663.

Wyrok SN z dnia 15 listopada 2010 r., IV CSK 78/10, Legalis nr 397169.

Wyrok SN z dnia 9 marca 2012 r., I CSK 277/11, Legalis nr 490930.

Wyrok SN z dnia 19 września 2013 r., I CSK 732/12, Legalis nr 924877.

Wyrok SN z dnia 6 listopada 2013 r., IV CSK 133/13, Legalis nr 830519.

Wyrok SN z dnia 18 grudnia 2013 r., I CSK 142/13, Legalis nr 830519.

Wyrok SN z dnia 12 marca 2015 r., I CSK 62/14, Legalis nr 1213078.

Wyrok SN z dnia 1 marca 2016 r., I PK 85/15, Legalis nr 1442658.

Wyrok SN z dnia 8 grudnia 2016 r., I CSK 1080/14, Legalis nr 1555647.

Wyrok TK z dnia 23 września 2003 r., K 20/02, Legalis nr 58777.

Wyrok TK z dnia 5 września 2005 r., P 18/04, Legalis nr 70000.

Wyrok TK z dnia 13 czerwca 2011 r., SK 41/09, Legalis nr 332311.

Wyrok WSA w Warszawie z dnia 23 września 2005 r., I SA/Wa 1692/04, Legalis nr 1131315.

Wyrok WSA w Warszawie z dnia 21 września 2006 r., I SA/Wa 957/06, Legalis nr 354308.

\section{SUMMARY}

This paper refers mainly to the issue of the so-called Warsaw land, which on 21 November 1945 were passed to the Treasury, by the decree of 26 October 1945 on Ownership and Usufruct of Land in the Area of the Capital City of Warsaw. Amendments to the Civil Code and the Administrative Procedure Code have made significant changes in the pursuit of claims for damages. The paper also presents the manner of claiming for damages according to the legal regulations that were binding before 1 September 2004, as well as at the time after the amendments to the Civil Code and the Administrative Procedure Code. The regards were also enriched by the current case law.

Keywords: annulment of the decision; the limitation period; interrupting; administrative proceedings; perpetual usufruct; a claim for damages 